\title{
Nitrite and Ammonia Assimilation by Anaerobic Continuous Cultures of Escherichia coli
}

\author{
By J. A. COLE, K. J. COLEMAN, B. E. COMPTON, \\ B. M. KAVANAGH AND C. W. KEEVIL \\ Department of Biochemistry, University of Birmingham BI5 $2 T T$
}

(Received 28 March 1974; revised 30 May 1974)

\begin{abstract}
SUMMARY
Anaerobic continuous cultures of Escherichia coli strains HfrC and KI 2-OR75 assimilated nitrite to produce $63.7 \mathrm{~g}$ dry mass/g-atom $\mathrm{N}$. Washout occurred when these cultures were aerated, or when the dilution rate was above $0.05 \mathrm{~h}^{-1}$. Nitrite reductase, glutamate dehydrogenase and glutamine synthetase activities and cytochrome $c_{552}$ synthesis were derepressed when growth of strain OR75 was limited by the concentration of either nitrite or ammonia in the reservoir. Glutamate synthase activity was far less than glutamate dehydrogenase, but was highest when nitrite limited growth. These results indicate that enzymes which catalyse glutamate synthesis from inorganic nitrogen compounds are regulated in an interdependent manner, but that glutamine synthetase protein is unlikely to be the aporepressor for glutamate dehydrogenase synthesis in this organism. Possible reasons for apparently opposite regulatory mechanisms in E. coli and Klebsiella aerogenes are discussed in the context of the selective pressures which are applied to bacteria in continuous culture. We conclude that $E$. coli KI 2 has alternative pathways for synthesizing glutamate, and because the $K_{m}$ of glutamate dehydrogenase for $\mathrm{NH}_{3}$ is $\mathrm{I} .6 \mathrm{mM}$, a growth-limiting concentration of an inorganic nitrogen compound in the reservoir would be assimilated predominantly by the glutamine synthetase-glutamate synthase pathway.
\end{abstract}

\section{INTRODUCTION}

Attempts in various laboratories to demonstrate growth of coliforms with nitrate as sole nitrogen source have yielded conflicting results, possibly because of variations in the media components, culture conditions and the strains used (McNall \& Atkinson, 1956; Zarowny \& Sanwal, I963; Fujita \& Sato, I966; Venables \& Guest, I968). There is little doubt, however, that various strains assimilate nitrate in media supplemented with small quantities of organic nitrogen compounds.

Far less is known about the assimilation of nitrite, the toxic product of nitrate reduction. Mutants of Escherichia coli KI2, deficient in nitrite reductase activity, have recently been isolated amongst bacteria that had survived penicillin treatment when nitrate or nitrite was the only nitrogen compound (J. A. Cole, unpublished). Because penicillin is lethal only to growing bacteria, this enrichment indicated that the wild type should be capable of assimilating nitrite. However, no colonies formed when bacteria were plated on to solid media containing nitrite, even when plates were incubated anaerobically. To develop a selective medium for isolating and characterizing new nitrite reductase mutants, we have investigated whether continuous cultures of $E$. coli can grow with nitrite as sole nitrogen source. We have compared yields of bacteria from anaerobic cultures in which growth was limited by the supply of ammonia or of nitrite in the feed and have measured the activities of enzymes 
of nitrogen metabolism in extracts of bacteria grown continuously with limited or excess nitrite or ammonia.

Most micro-organisms assimilate inorganic nitrogen compounds by one or both of two pathways in which glutamate is formed from ammonia and 2-oxoglutarate. Although other pathways have been proposed, for example the amination of fumarate to aspartate by aspartate- $\mathrm{NH}_{3}$ lyase, they are physiologically unimportant (Berberich, 1972). Some eukaryotes and many prokaryotes synthesize a glutamate dehydrogenase (GDH) that catalyses the reductive amination of 2-oxoglutarate to glutamate. The $K_{m}$ for GDH is very high ( $\mathrm{I}$ to $5 \mathrm{mM}$ ), so to maintain an adequate rate of glutamate synthesis when the concentration of $\mathrm{NH}_{3}$ is less than I mM, these organisms must either synthesize more GDH or utilize a more effective $\mathrm{NH}_{3}$-scavenging pathway. GDH activity was not detected in some Bacillus and Erwinia species (Meers, Tempest \& Brown, 1970); in these bacteria, glutamate is synthesized by an alternative pathway that involves two enzymes, glutamine synthetase (GS) and glutamate synthase [glutamine (amide): 2-oxoglutarate amino transferase oxidoreductase (NADP ${ }^{+}$); GOGAT]. The GS-GOGAT pathway is used preferentially by many prokaryotes and at least some eukaryotes when the nitrogen supply is growthlimiting (Brenchley, Prival \& Magasanik, I973; Brown, Burn \& Johnson, 1973). The enzymes for both pathways have been detected in several strains of $E$. coli and the regulation of glutamine synthesis in $E$. coli w has been studied in greater detail than for any other organism, but comparatively little is known about the relative regulation of the two glutamate pathways in this species. If nitrite reduction to $\mathrm{NH}_{3}$ is a slow, growth-limiting process, synthesis of GS and GOGAT might be derepressed even when the concentration of nitrite in the feed medium is high. This type of regulation has been observed with nitrogen-fixing cultures of Klebsellia pneumoniae (Nagatani, Shimizu \& Valentine, I97I).

It was important to distinguish between changes in enzyme activities due to changes in the nitrogen supply, and non-specific changes in activities of unrelated pathways due to variations in cell density or catabolite repression. Growth was therefore sulphur- rather than carbon-limited when the nitrogen source was in excess (see Hill, Drozd \& Postgate, 1972).

\section{METHODS}

Organisms and culture. Escherichia coli K12-OR75, a prototrophic $\mathrm{Hfr}$ isolated by R. Curtiss III, was a gift from F. B. Ward. Escherichia coli HfrC met-NCTCI0237 was obtained from the National Collection of Industrial Bacteria, Torrey Research Station, Aberdeen. Both organisms were maintained on nutrient agar slants at $4{ }^{\circ} \mathrm{C}$.

Nutrient broth (2.81) was sterilized in a 41 continuous fermentation vessel (L. H. Engineering Ltd, Stoke Poges, Buckinghamshire) and inoculated with $20 \mathrm{ml}$ of an overnight culture grown aerobically in nutrient broth. The culture was aerated until $E_{650}$ was above $\mathrm{r} \cdot 0$, and then gassed with $\mathrm{N}_{2}: \mathrm{CO}_{2}(95: 5, \mathrm{v} / \mathrm{v})$. The feed medium was added at $80 \mathrm{ml} / \mathrm{h}$ $(D=0.029)$. Temperature and $\mathrm{pH}$ were maintained at $37^{\circ} \mathrm{C}$ and $7 \cdot 2 \pm 0.05$, respectively. The ammonium salts medium contained, per litre distilled water: $5 \mathrm{~g} \mathrm{KH}_{2} \mathrm{PO}_{4}$, I $\mathrm{g}$ trisodium citrate, $0.2 \mathrm{ml}$ conc. $\mathrm{HCl}, \mathrm{I} 2 \mathrm{~g}$ glucose (sterilized separately), and $\mathrm{I} \mathrm{ml}$ of a sulphur-free trace metal solution (prepared by mixing $8.2 \mathrm{~g} \mathrm{MgCl}_{2} \cdot 7 \mathrm{H}_{2} \mathrm{O}, 1 \cdot 0 \mathrm{~g} \mathrm{MnCl}_{2} \cdot 4 \mathrm{H}_{2} \mathrm{O}, 0.4 \mathrm{~g}$ $\mathrm{FeCl}_{3} .6 \mathrm{H}_{2} \mathrm{O}, 0 \cdot 1 \mathrm{~g} \mathrm{CaCl}_{2}$ and $2 \mathrm{ml}$ conc. $\mathrm{HCl}$ in $\mathrm{IO} \mathrm{ml}$ distilled water). The sulphur source was $\mathrm{Na}_{2} \mathrm{SO}_{4}$ at $0 . \mathrm{I} \mathrm{mM}$ for sulphur-limited cultures, and at $0.4 \mathrm{~mm}$ for nitrogen- or carbonlimited cultures. When nitrite was the nitrogen source, $\mathrm{HCl}$ was omitted from the feed medium and $6.2 \mathrm{~g} \mathrm{~K}_{2} \mathrm{HPO}_{4} / 1$ replaced $5 \mathrm{~g} \mathrm{KH}_{2} \mathrm{PO}_{4} / 1$, because nitrite is unstable in acidic solution and gaseous ammonia is liberated from ammonium salts at high $\mathrm{pH}$. Sterile 
I $\mathrm{M}-\mathrm{NaNO}_{2}$ or $\mathrm{I} \mathrm{M}-\mathrm{NH}_{4} \mathrm{Cl}$ solutions were added to 81 batches of sterile feed medium to give a final concentration of $6 \mathrm{~mm}$ for nitrogen-limited cultures (unless otherwise noted), or $20 \mathrm{~mm}$ for sulphur-limited cultures. No attempt was made to exclude oxygen from the feed medium or from silicone tubing connexions. The purity and $E_{650}$ of the culture were checked with $20 \mathrm{ml}$ samples taken aseptically from a sampling port.

Bacteria for enzymic analyses were taken directly from the fermentation vessel. In a typical set of experiments, the nitrogen source in the feed medium was changed sequentially from $20 \mathrm{mM}-\mathrm{NaNO}_{2}$ to $20 \mathrm{mM}-\mathrm{NH}_{4} \mathrm{Cl}, 6 \mathrm{mM}-\mathrm{NH}_{4} \mathrm{Cl}$ and finally to $6 \mathrm{~mm}-\mathrm{NaNO}_{2}$. After $\mathrm{I}_{5} \mathrm{l}$ medium had passed through the fermenter, a 21 sample was harvested. A further 151 of the same medium was added at $80 \mathrm{ml} / \mathrm{h}$, and a second 21 sample was harvested. The fermenter was then refilled with the next medium in the sequence until a new steady-state resulted. The 21 samples were cooled to $4{ }^{\circ} \mathrm{C}$ and harvested by centrifugation at $10000 \mathrm{~g}$ for $\mathrm{I} 0 \mathrm{~min}$.

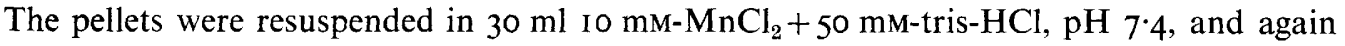
centrifuged at $10000 \mathrm{~g}$ for $10 \mathrm{~min}$. The washed pellet was drained and stored at $-20^{\circ} \mathrm{C}$.

Preparation of bacterial extracts. The bacterial pellet was thawed, mixed to a slurry with an equal volume of TEA buffer $\mathrm{pH} 8.0(50 \mathrm{~mm}$-tris $\mathrm{HCl}, 5 \mathrm{~mm}$-ethylenediamine tetraacetate $\mathrm{Na}_{2}{ }^{+}, 5 \mathrm{~mm}$-ascorbic acid) and broken in a Hughes (195I) press cooled to $-25^{\circ} \mathrm{C}$. High speed supernatant (HSS) and membrane (M) fractions were prepared as described previously (Cole \& Rittenberg, 197I) except that TEA buffer was used to prepare HSS extracts. Membranes were resuspended in $50 \mathrm{~mm}-\mathrm{Na}^{+} \mathrm{K}^{+}$phosphate $\mathrm{pH} 7.4$, sonicated for $3 \times 30 \mathrm{~s}$, sedimented by centrifugation for $20 \mathrm{~min}$ at $30000 \mathrm{~g}$, and resuspended in $50 \mathrm{~mm}$-phosphate $\mathrm{pH} 7 \% 4$.

Enzyme assays. Glutamate dehydrogenase activity was measured spectrophotometrically by recording the rate of NADPH oxidation after adding Io $\mu 1 \mathrm{HSS}$ (or Io $\mu 1$ of a suitable

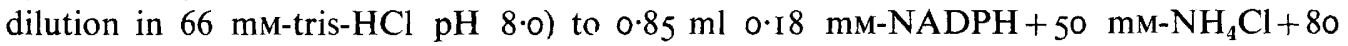
mM-tris- $\mathrm{HCl} \mathrm{pH} \mathrm{8.0.} \mathrm{After} 2 \mathrm{~min}, \mathrm{I} 50 \mu \mathrm{l} 20 \mathrm{~mm}$-2-oxoglutarate were added, and the rate of NADPH oxidation was again measured. The difference in rates with and without 2-oxoglutarate was proportional to the volume of extract added, but independent of the substrate concentrations. Where no ranges are given for spectrophotometric assays, replicates agreed to within I \%.

To measure GOGAT activity, the rate of oxidation of $0 \cdot 18 \mathrm{~mm}-\mathrm{NADPH}$ by to to $50 \mu 1$ HSS extract in $3.3 \mathrm{~mm}$-glutamine and $33 \mathrm{~mm}$-tris $\mathrm{HCl} \mathrm{pH} 8.0$ was determined. After $2 \mathrm{~min}, 2$-oxoglutarate was added to $5.0 \mathrm{mM}$. The increase in the rate of NADPH oxidation was independent of the 2-oxoglutarate concentration, and was proportional to the volume of HSS added. Brenchley (I973) reported that GOGAT from Klebsiella aerogenes lost $90 \%$ of its activity in Io min when incubated with NADPH and glutamine in the absence of 2oxoglutarate. It was possible, therefore, that we had seriously underestimated the GOGAT activity of our extracts. To check this, GOGAT activity was measured both by adding HSS after 2-oxoglutarate to start the reaction, and by adding 2-oxoglutarate to enzyme which had been incubated for various times with the other reagents. In a typical experiment, GOGAT from $E$. coli lost approximately $20 \%$ of its activity after Io min without 2-oxoglutarate; it was therefore appreciably more stable than the $K$. aerogenes enzyme. The instability of GOGAT from $E$. coli varied considerably between preparations, and in several experiments the two assay procedures gave identical results. It is possible, however, that some of the GOGAT activities reported in Fig. 3 below are up to $25 \%$ too low. In subsequent experiments rates of NADPH oxidation in the presence or absence of glutamine were determined separately.

Glutamine synthetase activities were measured by the transferase assay in mixed imidazole buffer $\mathrm{pH}_{7} \cdot \mathrm{I} 5$ (Shapiro \& Stadtman, $1970 \mathrm{~b}$ ). The buffer constituents and the $\mathrm{pH}$ for this assay 
were selected so that, with extracts of $E$. coli w, the rate of $\gamma$-glutamyl hydroxamate $(\gamma-\mathrm{GH})$ formation with $0.3 \mathrm{~mm}-\mathrm{Mn}^{2+}$ was proportional to the total concentration of active and in-

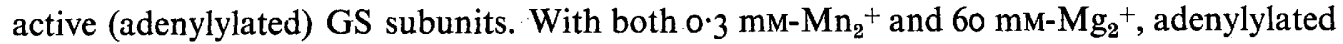
subunits were inactive and the observed rate was proportional to the concentration of enzymically active unadenylylated subunits (Shapiro \& Stadtman, 1970 $b$; but see also Prival, Brenchley \& Magasanik, 1973).

Reduced NADH-nitrite oxidoreductase activity (EC.1.6.6.4) was assayed with a Cary I4 spectrophotometer (Applied Physics Corp., Monrovia, California, U.S.A.), using Thunberg cuvettes that had been evacuated and filled repeatedly with 'white spot' nitrogen (British Oxygen). Reactions were started by adding 2 to $20 \mu 1$ HSS in $100 \mu 1$ TEA to $2.9 \mathrm{ml}$ $250 \mu \mathrm{M}-\mathrm{NADH}+\mathrm{I}$ mM-NAD ${ }^{+}$in TEA buffer. The difference in rates of NADH oxidation in the presence or absence of 2 mM- $\mathrm{NaNO}_{2}$ was proportional to the volume of HSS added (Cornish-Bowden, Ward \& Cole, I973).

Protein concentrations were determined by the Folin method (Lowry, Rosebrough, Farr \& Randall, I95I), and nitrite was determined as described by Cole \& Ward (1973). Cytochrome concentrations were measured by difference spectroscopy with either a Cary I4 or a Unicam SPI800 (Pye Unicam Ltd, Cambridge) spectrophotometer. Both test and reference samples $(3.0 \mathrm{ml} ; 2$ to $10 \mathrm{mg}$ protein $/ \mathrm{ml}$ ) were reduced with a few grains of sodium dithionite, and a base-line was recorded. The reference sample was partially reoxidized by about I $\mathrm{mg} \mathrm{NaNO}$, and the difference spectrum was recorded. A fresh sample of extract was then oxidized by about $0.1 \mathrm{mg} \mathrm{K}_{3} \mathrm{Fe}(\mathrm{CN})_{6}$ and used as the reference sample for a second difference spectrum. Peak heights at 552, 559 and $628 \mathrm{~nm}$ were determined, and cytochrome concentrations were calculated by assuming the molar extinction coefficient $\epsilon=24^{\circ} \circ$ for cytochrome $c_{552}$ (Fujita, I966) and 20.0 for cytochrome $b_{1}$. Cytochrome $d\left(a_{2}\right)$ concentrations are expressed as absorbance units/mg protein.

Glutamine (grade III), NADH (grade III), NAD ${ }^{+}$(grade III), NADPH, L-methionine sulphone and L-methionine-DL-sulphoximine were purchased from Sigma. All other chemicals were commercial samples of the highest available purity.

\section{RESULTS}

\section{Yields of bacteria during nitrite assimilation}

Escherichia coli strains HfrC or OR75 maintained steady-state anaerobic growth when the nitrogen source was either nitrite or ammonia. Washout occurred when air was supplied to cultures assimilating nitrite. Bacterial yields from equivalent concentrations of nitrite and ammonia were identical, and proportional to the concentration of nitrogen in the feed (Fig. I). Similar yields were also obtained when growth was limited by $0 \cdot 1$ mM-sulphate and the nitrogen was either $20 \mathrm{~mm}$-nitrite or $20 \mathrm{~mm}$-ammonia. No nitrite was detected in the culture supernatant under any growth condition, but the concentration of $\mathrm{NH}_{3}$ in supernatants from sulphate-limited cultures of $E$. coli OR75 was $12.3 \mathrm{~mm}$ when nitrite was in excess, and $12.7 \mathrm{~mm}$ when ammonia was in excess. Maximum growth rates were not determined for all conditions used, but washout occurred when the dilution rate of nitritelimited cultures of either strain was increased to 0.05 .

\section{Activities of enzymes for glutamate synthesis in E. coli OR75}

Higher activities of glutamate dehydrogenase were observed when cultures were nitrogenlimited than when they were sulphur-limited (Fig. 2a). This apparent derepression of GDH during nitrogen starvation was greatest when nitrite was the nitrogen source. Similar 


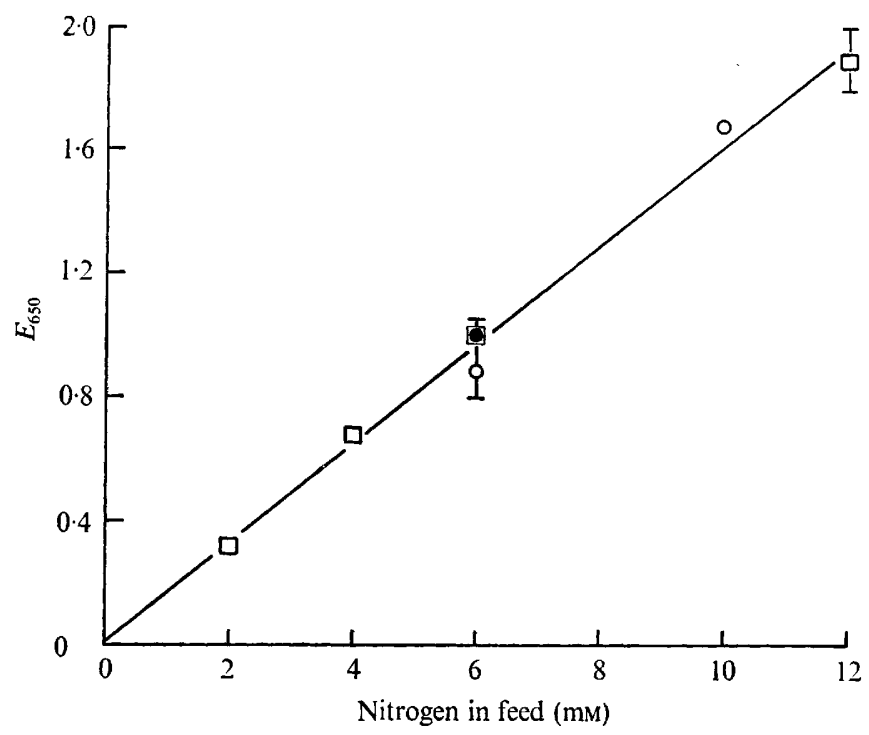

Fig. I. Effect of the nitrogen concentration in the reservoir on bacterial yield. Growth of continuous cultures of $E$. coli strains $\mathrm{HfrC}$ and $\mathrm{OR} 75$ was limited by the concentration of $\mathrm{NaNO}_{2}$ or $\mathrm{NH}_{4} \mathrm{Cl}$ in the reservoir $\left(1.2 \%, \mathrm{w} / \mathrm{v}\right.$, glucose; $\left.D=0.029 \mathrm{~h}^{-1}\right)$. An extinction of 1.0 at $650 \mathrm{~nm}$ corresponds to $395 \mathrm{mg}$ of bacterial dry wt/l: from tiic slope of the graph one can calculate that $63.7 \mathrm{~g}$ of bacterial dry wt are formed/g-atom N. $\square$, Strain $\mathrm{H}$.rc with limiting $\mathrm{NaNO}_{2} ; 0$, strain OR75 with limiting $\mathrm{NaNO}_{2}$; , strain OR75 with limiting $\mathrm{NH}_{4} \mathrm{Cl}$. Bars indicate the range observed when any steady state was repeated more than thrce times.

variations were found in the activities of glutamine synthetase, and the highest activities were observed when extracts of nitrite-limited bacteria were assayed with $60 \mathrm{mM}-\mathrm{Mg}^{2+}$ (Fig. $2 b$; Table I). In contrast, activities of GOGAT varied almost as much in extracts of bacteria grown in any one medium as in those grown in different media, but again highest activities were observed with nitrite-limited bacteria (Fig. 2c).

Enzymes for glutamate synthesis differ even in closely related organisms (Brown et al. 1973). It was therefore important to establish that assays which had been developed for other strains, species or genera were also valid for $E$. coli KI2. The $K_{m}$ for GDH from a nitrite-limited culture was determined by assaying the enzyme at various $\mathrm{NH}_{4} \mathrm{Cl}$ concentrations, but at constant concentrations of enzyme, 2-oxoglutarate and NADPH. The $K_{m}$ for ammonia was calculated to be I. $6 \mathrm{~mm}$. This high value made it more difficult to eliminate the possibility that the apparent GOGAT activities, which were far lower than the GDH activities, were due to reaction of GDH with traces of $\mathrm{NH}_{3}$ released from glutamine by glutaminase, or by a more complex reaction sequence. The effects of various concentrations of L-methionine-DL-sulphoximine and L-methionine sulphone on the activities of GDH and GOGAT were therefore measured (Fig. 3). GOGAT was $65 \%$ inhibited by I00 mM-L-methionine-DL-sulphoximine and $76 \%$ inhibited by $10 \mathrm{mM}-\mathrm{L}-\mathrm{methionine}$ sulphone. GDH activity was unaffected by either compound at any concentration tested.

In many of the previous experiments, GS activity was stimulated rather than inhibited by $\mathrm{Mg}^{2+}$ (Table $\mathrm{I}$; see also Prival et al. 1973). This was not surprising, because growth with excess glucose would favour a high intracellular concentration of 2-oxoglutarate which is an inhibitor of the GS adenylylating enzyme and an activator of the deadenylylation enzyme (Shapiro \& Stadtman, I970 a). To test whether GS activity from $E$. coli OR 75 was regulated 


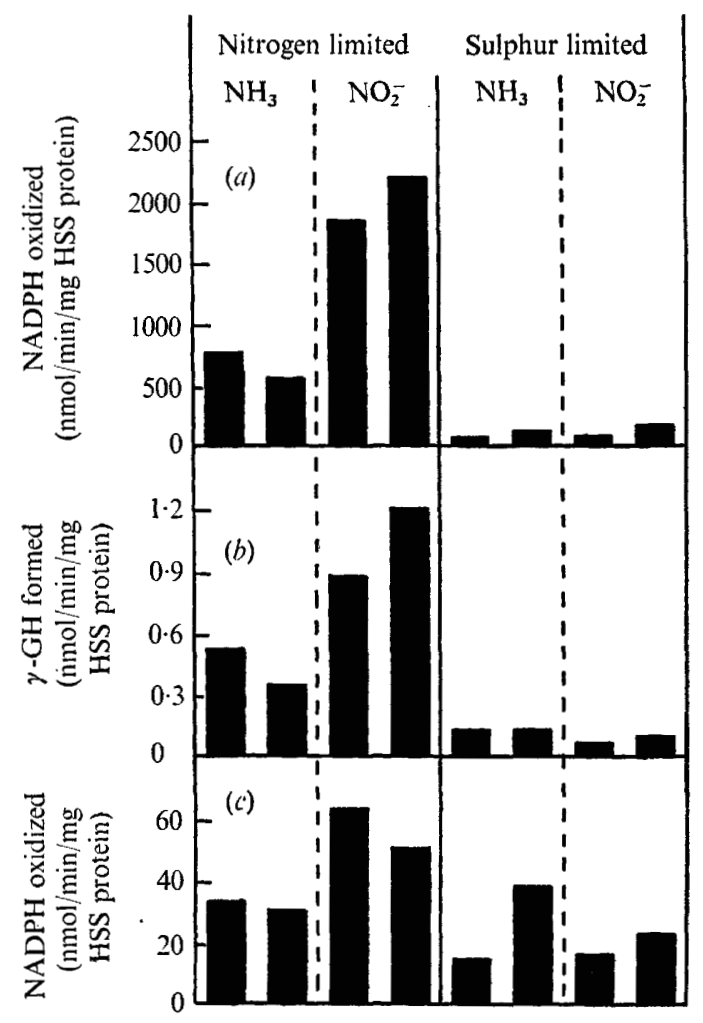

Fig. 2. (a) Glutamate dehydrogenase, (b) glutamine synthetase, and (c) glutamate synthase activities in $E$. coli OR75. Growth in anaerobic continuous cultures was limited by the concentration of $\mathrm{NaNO}_{2}$ or $\mathrm{NH}_{4} \mathrm{Cl}$ in the feed, or by the concentration of $\mathrm{Na}_{2} \mathrm{SO}_{4}$ when $\mathrm{NaNO}_{2}$ or $\mathrm{NH}_{4} \mathrm{Cl}$ were in excess. Each bar in the histogram shows the mean activity of duplicate assays for independent HSS preparations. Nitrogen-limited cultures were supplied with $6 \mathrm{~mm}-\mathrm{NH}_{4} \mathrm{Cl}$ or $6 \mathrm{~mm}-\mathrm{NaNO}_{2}$, and $0.4 \mathrm{~mm}_{-} \mathrm{Na}_{2} \mathrm{SO}_{4}$ as sulphur source. Concentrations of $\mathrm{NH}_{4} \mathrm{Cl}$ and $\mathrm{NaNO}_{2}$ were increased to $20 \mathrm{~mm}$ for sulphur-limited cultures, and the $\mathrm{Na}_{2} \mathrm{SO}_{4}$ concentration was reduced to $0.1 \mathrm{~mm}$. $D=0.029 \mathrm{~h}^{-1}$.

\section{Table I. The effect of $60 \mathrm{mM}-\mathrm{Mg}^{2+}$ on glutamine synthetase activities in E. coli OR75}

Each line of data is the mean activity of 4 to 9 determinations on one bacterial extract.

\begin{tabular}{|c|c|c|c|}
\hline \multirow[b]{2}{*}{ Nitrogen source } & \multirow[b]{2}{*}{ Limiting nutrient } & \multicolumn{2}{|c|}{$\begin{array}{l}\text { Glutamine synthetase activity } \\
\text { (nmol } \gamma \text {-GH formed/min/mg prote }\end{array}$} \\
\hline & & $+\mathrm{Mg}^{2+}$ & $-\mathrm{Mg}^{2+}$ \\
\hline $6 \mathrm{~mm}-\mathrm{NH}_{4} \mathrm{Cl}$ & $\mathbf{N}$ & $\begin{array}{l}575 \\
450\end{array}$ & $\begin{array}{l}522 \\
380\end{array}$ \\
\hline $6 \mathrm{mM}-\mathrm{NaNO}_{2}$ & $\mathrm{~N}$ & $\begin{array}{l}1960 \\
1450\end{array}$ & $\begin{array}{l}\text { I1 } 30 \\
2800^{*}\end{array}$ \\
\hline $20 \mathrm{mM}-\mathrm{NH}_{4} \mathrm{Cl}$ & $S$ & $\begin{array}{l}130 \\
120\end{array}$ & $\begin{array}{l}130 \\
120\end{array}$ \\
\hline $20 \mathrm{mM}-\mathrm{NaNO}_{2}$ & $\mathrm{~S}$ & $\begin{array}{r}63 \\
136\end{array}$ & $\begin{array}{l}63 \\
93\end{array}$ \\
\hline
\end{tabular}

* This measurement was repeated 3 times ( 8 assay tubes) because only this enzyme preparation from six independent samples was inhibited by $\mathrm{Mg}^{2+}$ : the datum is included because the same extract contained 'typical' activities of all other enzymes and cytochromes whose values are presented in other Figures or Tables. 


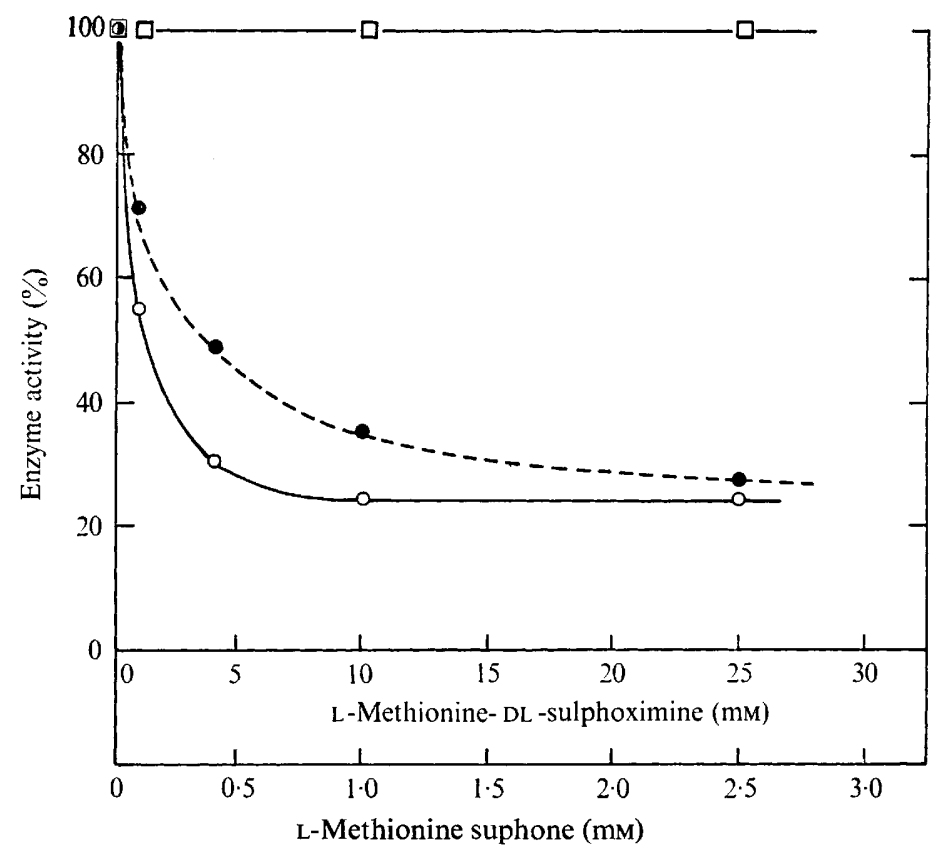

Fig. 3. Effect of L-methionine-DL-sulphoximine and L-methionine sulphone on the activities of glutamate synthase and glutamate dehydrogenase. Enzyme activities are expressed as the percentage of the activity in the absence of inhibitor. Each point is the mean of duplicate assays. $\square$, Glutamate dehydrogenase with either inhibitor; 0 , GOGAT with L-methionine-DL-sulphoximine; $O$, GOGAT with L-methionine sulphone.

Table 2. The effects of glutamate and carbon-limitation on the activities of enzymes for glutamate synthesis in E. coli OR75

\begin{tabular}{|c|c|c|c|c|c|}
\hline \multirow{3}{*}{$\begin{array}{l}\text { Nitrogen } \\
\text { source }\end{array}$} & \multirow{3}{*}{$\begin{array}{l}\text { Limiting } \\
\text { nutrient }\end{array}$} & \multicolumn{4}{|c|}{ Enzyme activity* } \\
\hline & & \multirow{2}{*}{$\begin{array}{c}\text { Glutamate } \\
\text { dehydrogenase }\end{array}$} & \multirow{2}{*}{$\begin{array}{c}\text { Glutamate } \\
\text { synthase } \\
\text { (GOGAT) }\end{array}$} & \multicolumn{2}{|c|}{ Glutamine synthetase } \\
\hline & & & & $+\mathrm{Mg}^{2+}$ & $-\mathrm{Mg}^{2+}$ \\
\hline $\mathrm{NO}_{2}$ & $\mathbf{N}$ & I630 & $62 \cdot 0$ & I 100 & 800 \\
\hline $\mathrm{O}_{2}+5 \mathrm{~mm}-\mathrm{Na}^{+}$glutamate & $\mathrm{N}$ & 2900 & $72 \cdot 0$ & 890 & I940 \\
\hline & $\mathrm{C}$ & 990 & $56 \cdot 5$ & 120 & 250 \\
\hline
\end{tabular}

* Units are nmol NADPH oxidized or $\gamma$-glutamyl hydroxamate formed $/ \mathrm{min} / \mathrm{mg}$ protein.

by an adenylylation-deadenylylation cycle, anaerobic growth was limited sequentially by Io mM- $\mathrm{NO}_{2}^{-}, 5 \mathrm{mM}^{-} \mathrm{NO}_{2}^{-}$and $5 \mathrm{~mm}$-glutamate, and by $0.6 \%(\mathrm{w} / \mathrm{v})$ glucose when 60 mM- $\mathrm{NH}_{4} \mathrm{Cl}$ was the nitrogen source (Table 2). The $\mathrm{Mn}^{2+}$-dependent GS activity increased when part of the nitrogen was supplied as glutamate, but much of this enzyme was inhibited by $60 \mathrm{~mm}-\mathrm{Mg}^{2+}$. Extracts from glucose-limited cultures contained far less GS activity, and $53 \%$ of this was inhibited by $\mathrm{Mg}^{2+}$ (Table 2 ). GDH activity was significantly greater when half of the limited nitrogen supply was sodium glutamate (Table 2 ). 


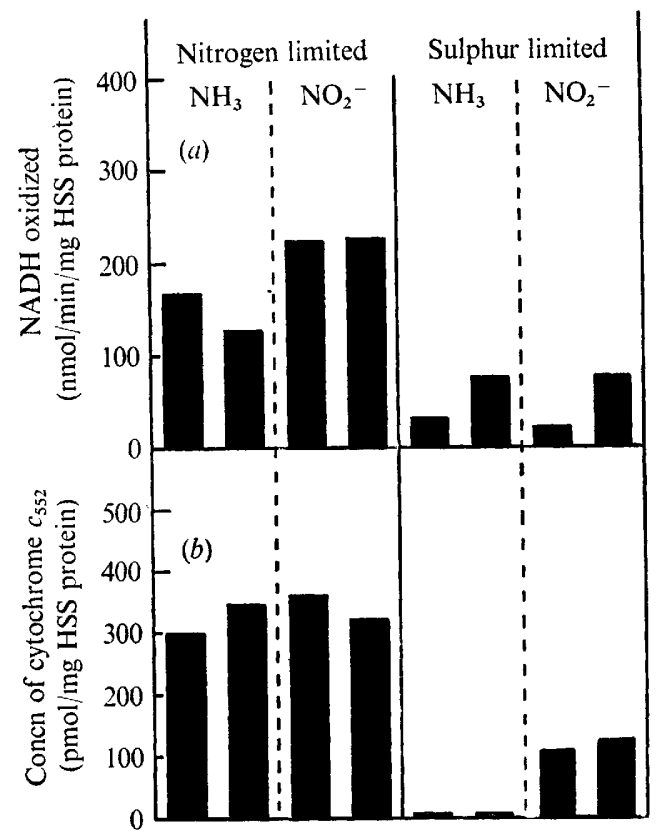

Fig. 4. (a) Nitrite reductase activity, and (b) concentration of cytochrome $c_{552}$ in E. coli OR 75 from nitrogen- or sulphur-limited continuous cultures. Experimental details were as in Fig. 3.

Table 3. Concentrations of cytochromes $b$ and $d\left(a_{2}\right)$ in membranes, and of cytochrome $c_{552}$ in extracts

Each line of data refers to an independent sample of bacteria. Cytochrome concentrations are the mean of the two determinations.

\begin{tabular}{|c|c|c|c|c|c|}
\hline Nitrogen source & $\begin{array}{l}\text { Limiting } \\
\text { nutrient }\end{array}$ & $\begin{array}{c}\text { Cytochrome } c_{552} \\
\left(\mathrm{NO}_{2}^{-}\right)^{*} \\
\text { (pmol/mg protein) }\end{array}$ & $\begin{array}{c}\text { Cytochrome } c_{552} \\
\left(\mathrm{Fe}^{3+}\right) \dagger \\
(\mathrm{pmol} / \mathrm{mg} \text { protein) }\end{array}$ & $\begin{array}{c}\text { Cytochrome } b \\
\left(\mathrm{Fe}^{3+}\right) \dagger \\
(\mathrm{pmol} / \mathrm{mg} \text { protein) }\end{array}$ & $\begin{array}{c}\text { Cytochrome } d \\
\left(\mathrm{NO}_{2}^{-}\right)^{*} \\
\left(E_{628} / \mathrm{mg}^{2} \text { protein }\right)\end{array}$ \\
\hline $6 \mathrm{~mm}^{-\mathrm{NH}_{4}} \mathrm{Cl}$ & $\mathbf{N}$ & $\begin{array}{l}25 \mathrm{I} \\
3 \mathrm{I} 2\end{array}$ & $\begin{array}{l}300 \\
345\end{array}$ & $\begin{array}{l}492 \\
252\end{array}$ & $\begin{array}{l}0.0019 \\
0.0018\end{array}$ \\
\hline $6 \mathrm{mM}-\mathrm{NaNO}_{2}$ & $\mathbf{N}$ & $\begin{array}{l}292 \\
270\end{array}$ & $\begin{array}{l}358 \\
310\end{array}$ & $\begin{array}{l}210 \\
200\end{array}$ & $\begin{array}{l}0.0045 \\
0.0045\end{array}$ \\
\hline $20 \mathrm{~mm}-\mathrm{NH}_{4} \mathrm{Cl}$ & $\mathbf{S}$ & $\begin{array}{l}0 \\
0\end{array}$ & $\begin{array}{l}0 \\
0\end{array}$ & $\begin{array}{l}157 \\
282\end{array}$ & $\begin{array}{l}0.0011 \\
0.0010\end{array}$ \\
\hline $20 \mathrm{~mm}-\mathrm{NaNO}_{2}$ & $\mathbf{S}$ & $\begin{array}{l}103 \\
\text { II } 4\end{array}$ & $\begin{array}{l}125 \\
108\end{array}$ & $\begin{array}{l}352 \\
355\end{array}$ & $\begin{array}{l}0.0033 \\
0.0026\end{array}$ \\
\hline
\end{tabular}

* Reference sample reduced by dithionite, and then partially reoxidized by $\mathrm{NaNO}_{2}$ (in cuvettes open to the air).

$\dagger$ Reference sample oxidized by $\mathrm{K}_{2} \mathrm{Fe}(\mathrm{CN})_{6}$.

\section{Nitrite reductase activities and cytochrome concentrations}

NADH-nitrite oxidoreductase activity was highest in HSS extracts of bacteria from nitrogen-limited cultures when either nitrite or ammonia was the nitrogen source (Fig. $4 a$ ). Far lower activities were detected when excess nitrogen was supplied, but again there was no significant difference in this activity in bacteria grown with excess nitrite or excess ammonia.

Cytochrome $c_{552}$ has been implicated as a component of the major pathway for nitrite 


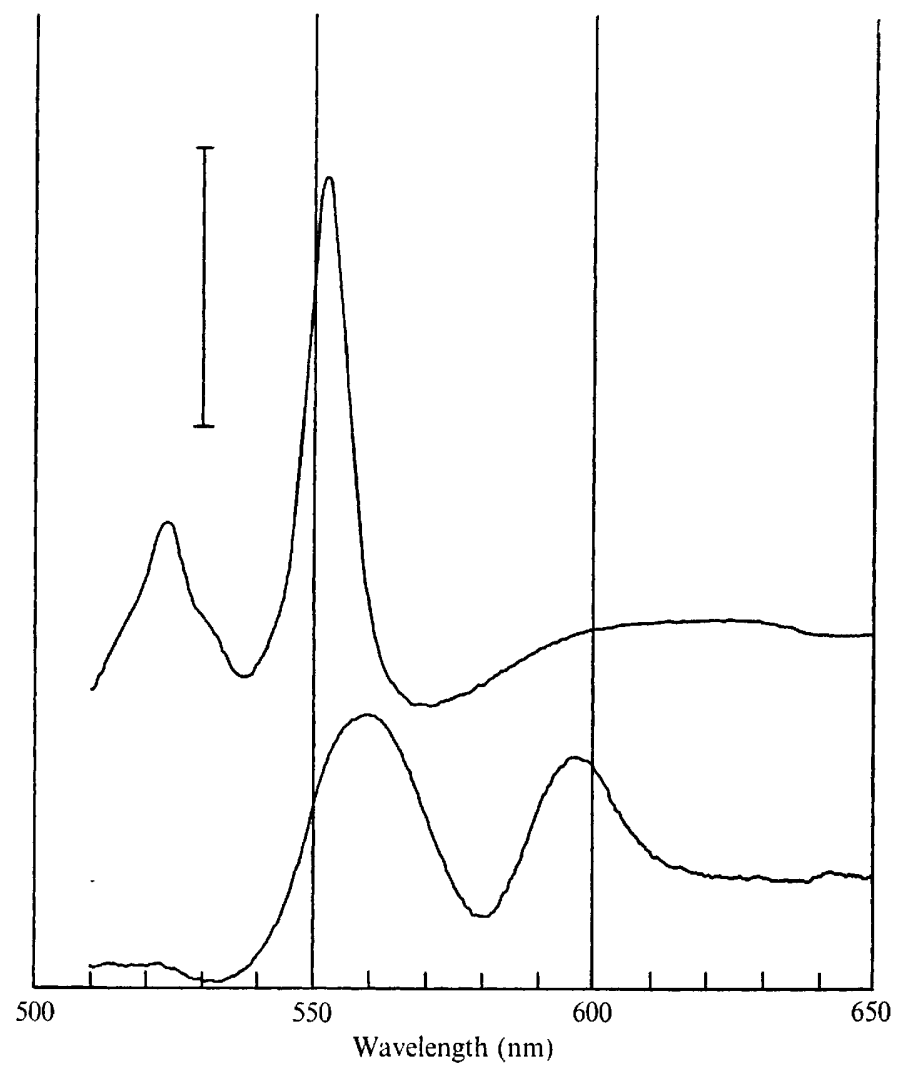

Fig. 5. Difference spectra of soluble cytochromes from $E$. coli strain OR75 grown in continuous culture with limited or excess $\mathrm{NH}_{4} \mathrm{Cl}$ as nitrogen source. Test and reference samples $(2.0 \mathrm{ml})$ were reduced with a few grains of sodium dithionite, and the reference sample was partially reoxidized with about I mg $\mathrm{NaNO}_{2}$. Upper curve: HSS (14.8 mg protein/ml) from a culture limited by $6 \mathrm{mM}-\mathrm{NH}_{4} \mathrm{Cl}$. Lower curve: HSS $(27.9 \mathrm{mg}$ protein $/ \mathrm{ml})$ from a culture limited by $0.1 \mathrm{~mm}-\mathrm{Na}_{2} \mathrm{SO}_{4}$ $\left(20 \mathrm{~mm}-\mathrm{NH}_{4} \mathrm{Cl}\right.$ ). The vertical bar corresponds to an absorbance increment of 0.05 . Spectra were recorded at $\mathrm{I} 8$ to $20^{\circ} \mathrm{C}$ with a Unicam SPI 800 spectrophotometer.

reduction in E. coli (Cole \& Ward, 1973). Highest concentrations of this cytochrome were found in HSS extracts of bacteria grown with limiting nitrite or limiting ammonia, but none was found in bacteria grown with excess ammonia (Fig. $4 \mathrm{~b}$ ). The ratio of the cytochrome $c_{552}$ concentration to the nitrite reductase activity varied with different growth conditions, but high cytochrome concentrations were never found in extracts with low nitrite reductase activity. The concentration of cytochrome $b$ in $\mathbf{M}$ extracts varied less than cytochrome $c_{552}$ in HSS extracts, and the observed changes did not correlate with the type of nitrogen source or its abundance (Table 3). Cytochrome $d$ was most easily detected when the reference sample for M spectra was oxidized by nitrite (Table 3). Peak heights at $628 \mathrm{~nm}$ were smaller and irreproducible when ferricyanide was the oxidant.

Although HSS extracts of bacteria grown with excess $\mathrm{NH}_{4} \mathrm{Cl}$ contained little or no cytochrome $c_{552}$, broad peaks in their difference spectra were observed at 559 to $560 \mathrm{~nm}$ and 595 to $597 \mathrm{~nm}$ (Fig. 5). When nitrite was growth-limiting, M cytochromes which had been reduced by dithionite were partially reoxidized by $\mathrm{NaNO}_{2}$ (Fig. 6). Peaks at 552 and $628 \mathrm{~nm}$ were observed, but the $55^{2} \mathrm{~nm}$ peak (presumed to be due to membrane-bound 


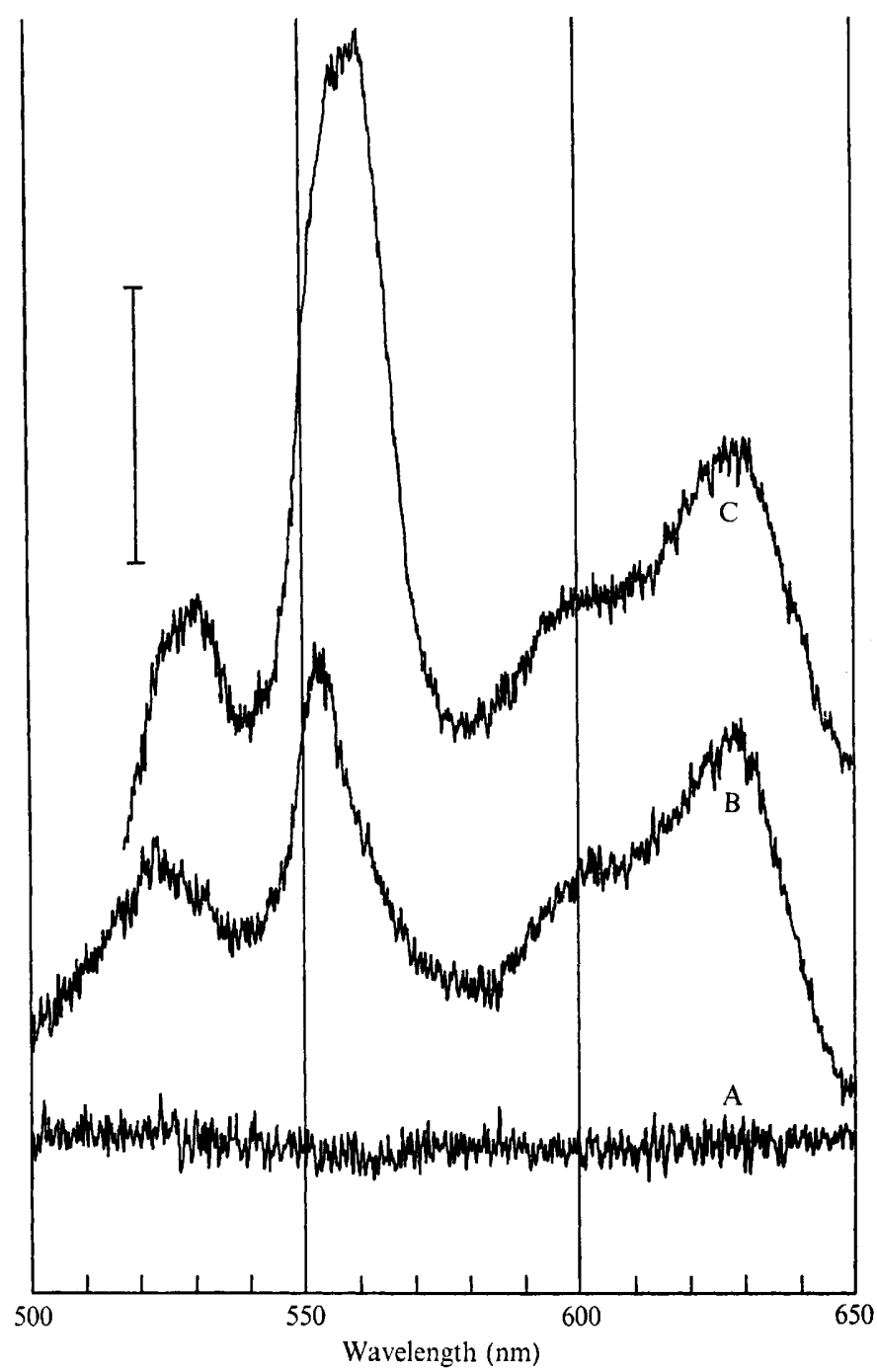

Fig. 6. Difference spectra of membrane-bound cytochromes from $E$. coli Hfrc grown with a limiting concentration of $\mathrm{NaNO}_{2}(6 \mathrm{~mm})$. Curve $A$, base line with test and reference sample reduced by a few grains of sodium dithionite. Curve B, reference samples partially reoxidized by about $\mathrm{I} \mathrm{mg}$ $\mathrm{NaNO}_{2}$. Curve $\mathrm{C}$, fresh reference sample oxidized by $\mathrm{K}_{3} \mathrm{Fe}(\mathrm{CN})_{6}$. Protein concentrations were $6.8 \mathrm{mg} / \mathrm{ml}$. The vertical bar corresponds to an absorbance increment of 0.05 .

cytochrome $c_{552}$ ) was far more pronounced with $\mathbf{M}$ extracts from $E$. coli strain Hfrc than from strain OR75. When the reference sample of the same preparation had been oxidized by $\mathrm{K}_{3} \mathrm{Fe}\left(\mathrm{CN}_{6}\right)$, peaks at 559 and $628 \mathrm{~nm}$ were observed, together with a poorly defined cytochrome $a_{1}$ peak at $595 \mathrm{~nm}$ (Fig. 6).

\section{DISCUSSION}

Identical yields of $E$. coli strains HfrC and oR75 were obtained from equimolar concentrations of nitrite or ammonia $(63.7 \mathrm{~g} / \mathrm{g}$-atom $\mathrm{N}$ at $D=0.029)$ (Fig. I). It is unlikely, therefore, that nitrogen atoms were lost as gaseous denitrification products when growth 
was limited by nitrite. The high activities of enzymes for nitrite reduction and glutamate and glutamine synthesis in nitrogen-limited cultures, and their repression when nitrogen was in excess, provide further evidence that various pathways of nitrogen metabolism are regulated in an interdependent manner (Meers et al. 1970; Nagatani et al. 197I; Brenchley et al. 1973; Prival et al. 1973). Furthermore, nitrite reductase activity and cytochrome $c_{552}$ synthesis appear to be regulated like other enzymes for glutamate synthesis: they are not derepressed in proportion to the concentration of nitrite in the feed as one might expect if their primary function was to detoxify nitrite. The physiological significance of membrane-bound cytochromes $c$ and $d$ in bacteria assimilating a limited supply of nitrite will be discussed in a subsequent report.

The correlation between high activities of GDH and GS in nitrogen-limited cultures was unexpected because it is inconsistent with one suggested mechanism for GDH regulation. Brenchley et al. (I973) described mutants of $K$. aerogenes that lacked GOGAT activity and were unable to grow in minimal media with less than $\mathrm{r} m M-\mathrm{NH}_{3}$. A subsequent mutation resulted in constitutive synthesis of GS and complete repression of GDH. It was suggested that GS protein was the key component for regulating the synthesis of enzymes supplying glutamate. They suggested that GS was formed when the intracellular concentration of glutamine was low, and that this enzyme repressed GDH synthesis. Such an explanation clearly cannot be extended to continuous cultures of $E$. coli KI2, even if one suggests that it is the adenylylated, $\mathrm{Mg}^{2+}$-sensitive form of GS that represses GDH synthesis. Although both nitrogen- and sulphur-limited bacteria yielded GS that was insensitive to $\mathrm{Mg}^{2+}$ and was therefore presumably unadenylylated, this form of the enzyme would also have been favoured by the growth conditions used to demonstrate the reciprocal regulation of GDH and GS in other bacteria. Similar arguments make it unlikely that the repressor complex is either glutamine or glutamate bound to GS protein. It has been emphasized that, although regulatory functions have been conserved during evolution, regulatory mechanisms differ even in closely related organisms (Shapiro \& Stadtman, 1970a). Also, mutant strains with altered regulatory mechanisms might be selected during prolonged experimentation with continuous cultures, even during the delay while a new steady state is being achieved. For these reasons, we are reluctant to extrapolate our observations to other organisms, but offer two explanations of them. One is that GS is derepressed, when the intracellular concentration of $\mathrm{NH}_{3}$ is low, to synthesize glutamate by the more effective GS-GOGAT pathway; however, the low intracellular concentration of glutamate and the high concentration of 2-oxoglutarate also favour derepression of GDH. An alternative explanation of our data is that the high activities of GDH and GS exert a mass-action effect to maintain sufficient rates of glutamate and glutamine synthesis when the supply of nitrogen is limiting. GOGAT would then be a redundant enzyme, and one should question the significance and validity of its reported activity. Three lines of evidence suggest that the GOGAT assay measured an enzyme other than GDH. First, although the GOGAT activity was low, it was not a constant proportion of the GDH activity. It is therefore unlikely that the slow oxidation of NADPH was due to GDH reacting with traces of $\mathrm{NH}_{3}$ added as an impurity of the glutamine, or released from glutamine by glutaminase. Second, the apparent GOGAT activity did not vary significantly with different growth conditions: this was as expected (Miller \& Stadtman, 1972). Finally, GOGAT activity was substantially inhibited by concentrations of L-methionine-DL-sulphoximine and L-methionine sulphone that had no effect on GDH (Fig. 3). The low activity of GOGAT relative to GDH prevented us from establishing whether the two activities were 'non-additive', as has been reported for $E$. coli strain B/r (Savageu, Kotre \& Sakamoto, 1972). 
We conclude, therefore, that anaerobic cultures of E. coli $\mathrm{K} I 2$ have alternative pathways for synthesizing glutamate from $\mathrm{NH}_{3}$, and that the GS-GOGAT pathway would be used preferentially when the nitrogen supply is growth-limiting. The molecules which regulate the synthesis of enzymes of inorganic nitrogen metabolism have yet to be identified.

\section{REFERENCES}

BERBERICH, M. A. (1972). A glutamate-dependent phenotype in Escherichia coli $\mathrm{KI} 2$ : the result of two mutations. Biochemical and Biophysical Research Communications 47, I498-1503.

BRENCHLEY, J. E. (1973). Effects of methionine sulfoximine and methionine sulfone on glutamate synthesis in Klebsiella aerogenes. Journal of Bacteriology $\mathbf{1 4}, 666-673$.

Brenchley, J.E., Prival, M. J. \& Magasanik, B. (1973). Regulation of the synthesis of enzymes responsible for glutamate formation in Klebsiella aerogenes. Journal of Biological Chemistry 248, 61 22-61 28.

Brown, C. M., Burn, V. J. \& Johnson, B. (1973). Presence of glutamate synthase in fission yeasts and its possible role in ammonia assimilation. Nature New Biology 246, I I5-116.

Cole, J. A. \& RITTENBERG, S. C. (1971). A comparison of respiratory processes in Spirillum volutans, Spirillum itersonii and Spirillum serpens. Journal of General Microbiology 69, 375-383.

COLE, J. A. \& WARD, F. B. (I973). Nitrite reductase-deficient mutants of Escherichia coli KI2. Journal of General Microbiology 76, $21-29$.

Cornish-Bowden, A. J., WARD, F. B. \& Cole, J. A. (1973). Product activation and 'redox control' of nitrite reductase activity in Escherichia coli. Journal of General Microbiology 76, xi.

FujiTA, T. (1966). Studies on soluble cytochromes in Enterobacteriaceae. I. Detection, purification and properties of cytochrome $c-552$ in anaerobically grown cells. The Journal of Biochemistry 60, 204-215.

Fujita, T. \& SATo, R. (1966). Studies on soluble cytochromes in Enterobacteriaceae. III. Localization of cytochrome $c-552$ in the surface layer of cells. The Journal of Biochemistry 6o, 568-577.

Hill, S., Drozd, J. W. \& Postgate, J. R. (1972). Environmental effects on the growth of nitrogen-fixing bacteria. Journal of Applied Chemistry and Biotechnology 22, 541-558.

Hughes, D. E. (195I). A press for disrupting bacteria and other microorganisms. British Journal of Experimental Pathology 32, 97-109.

Lowry, O. H., Rosebrough, N. J., Farr, A. L. \& Randall, R. J. (1951). Protein measurement with the Folin phenol reagent. Journal of Biological Chemistry I93, 265-275.

MCNALl, E. G. \& ATKinson, D. E. (1956). Nitrate reduction. I. Growth of Escherichia coli with nitrate as sole nitrogen source. Journal of Bacteriology 72, 226-229.

MeERs, J. L., TeMPEST, D. W. \& Brown, C. M. (1970). 'Glutamine(amide): 2-oxoglutarate amino transferase oxido-reductase (NADP)', an enzyme involved in the synthesis of glutamate by some bacteria. Journal of General Microbiology 64, I87-194.

Miller, R. E. \& STAdtMan, E. R. (1972). Glutamate synthase from Escherichia coli. An iron-sulphide flavoprotein. Journal of Biological Chemistry 247, 7407-7419.

Nagatani, H., Shimizu, M. \& Valentine, R. C. (1971). The mechanism of ammonia assimilation in nitrogen fixing bacteria. Archiv für Mikrobiologie 79, I64-175.

Prival, M. J., Brenchley, J. E. \& MagasaniK, B. (1973). Glutamine synthetase and the regulation of histidine formation in Klebsiella aerogenes. Journal of Biological Chemistry 248, 4334-4343.

Savageu, M. A., Kotre, A. M. \& SaKamoto, N. (I972). A possible role in the regulation of primary amination for a complex of glutamine: $\alpha$ ketoglutarate amidotransferase and glutamate dehydrogenase in Escherichia coli. Biochemical and Biophysical Research Communications 48, 4I-47.

Shaptro, B. M. \& StadtMAn, E. R. (I970a). The regulation of glutamine synthesis in microorganisms. Annual Review of Microbiology 24, 50I-524.

Shapiro, B. M. \& Stadtman, E. R. (I970b). Glutamine synthetase (Escherichia coli). In Methods in Enzymology, vol. 17A, pp. 910-922. Edited by S. P. Colowick and N. O. Kaplan. New York: Academic Press.

Venables, W. A. \& Guest, J. R. (1968). Transduction of nitrate reductase loci of Escherichia coli by phages PI and lambda. Molecular and General Genetics 103, I27-140.

ZARownY, D. P. \& SANWAL, B. D. (1963). Characterization of a nicotinamide adenine dinucleotide specific nitrite reductase from Escherichia coli, strain K 12. Canadian Journal of Microbiology 9, 53 I-539. 